\title{
WEB E-COMMERCE DENGAN SISTEM PREDIKSI TRANSAKSI PENJUALAN MENGGUNAKAN METODE K-NEAREST NEIGHBOR
}

\author{
Denny Pribadi ${ }^{1}$, Rizki Ramadhan ${ }^{2}$, Rizal Amegia Saputra ${ }^{3}$, Jamal Maulana Hudin ${ }^{4}$ \\ ${ }^{1,2}$ STMIK Nusa Mandiri Sukabumi \\ JI. Veteran II No. 20A, Sukabumi \\ e-mail: denny.dpi@nusamandiri.ac.id.,1202rr@gmail.com \\ ${ }^{3}$ AMIK BSI Sukabumi \\ Jl. Cemerlang No 8 Sukakarya, Sukabumi \\ e-mail: rizal.rga@bsi.ac.id \\ ${ }^{4}$ STMIK Nusa Mandiri Jakarta \\ Jl. Damai No. 8, Warung Jati Barat (Margasatwa), Pasar Minggu, Jakarta Selatan \\ e-mail: jamal.jml@nusamandiri.ac.id
}

\begin{abstract}
Abstrak
Besarnya angka pengguna internet di Indonesia semakin membuka peluang bisnis baik di tingkat lokal maupun global. Perusahaan kecil dan besar berlomba-lomba memanfaatkan internet demi menunjang bisnis mereka. Penerapan teknologi e-commerce merupakan salah satu faktor yang penting untuk menunjang keberhasilan penjualan suatu produk dari sebuah perusahaan. Sistem prediksi jumlah transaksi penjualan dapat diterapkan pada aplikasi $e-$ commerce. Metode K-Nearest Neighbor digunakan karena memiliki akurasi yang tinggi dengan rasio kesalahan kecil. Adapun hasil dari prediksi atau peramalan bermanfaat untuk membantu meningkatkan omzet penjualan perusahaan. Studi kasus penelitian ini dilakukan di Distro Folder yang merupakan perusahaan yang bergerak dalam bidang penjualan pakaian seperti baju, jaket, celana, topi, tas dan aksesoris lainnya di Sukabumi. Dengan menggunakan website pembeli dapat lebih mudah dalam memilih dan memesan barang kapanpun dan dimanapun tanpa harus mengunjungi distro. Pembangunan website e-commerce yang memiliki sistem prediksi transaksi penjualan menggunakan metode K-Nearest Neighbour diharapkan dapat meningkatkan angka penjualan dengan lebih cepat, lebih luas jangkauan pasarnya serta lebih mudah dalam mengelola laporan penjualan.
\end{abstract}

Kata Kunci: E-commerce, K-Nearest Neighbor, Web

\begin{abstract}
The large number of internet users in Indonesia increasingly opened business opportunities both at local and global levels. Small and big companies vying to use the internet to support their business. Application of e-commerce technology is one important factor to support the successful sale of a product of a company. The prediction system of the number of sales transactions can be applied to e-commerce applications. The K-Nearest Neighbor method is used because it has high accuracy with small error ratios. The result of prediction or forecasting is useful to help increase sales turnover of the company. Case study of this research is done in Distro Folder which is a company engaged in the sale of clothes such as clothes, jackets, pants, hats, bags and other accessories in Sukabumi. By using the buyer's website can be easier in choosing and ordering goods anytime and anywhere without having to visit the distro. The development of e-commerce website that has a sales transaction prediction system using $\mathrm{K}$ Nearest Neighbors method is expected to increase sales figures with faster, wider range of market and easier in managing sales report.
\end{abstract}

Keywords: E-commerce, K-Nearest Neighbor, Web 


\section{Pendahuluan}

Internet telah merevolusi cara dunia melakukan bisnis baik di tingkat lokal dan global. Dari cara mengumpulkan data untuk merekrut karyawan pada perusahaan, cara menggunakan internet sangat banyak, sebagai manfaat dari internet untuk komunitas bisnis. Orang telah menemukan berbagai manfaat internet untuk bisnisnya. Banyak perusahaan kecil dan besar telah memanfaatkan internet demi menunjang bisnis mereka. Bahkan ada yang dinamakan bisnis Online dimana semata-mata menjadikan internet sebagai bisnis utama (Marius, P., \& Pinotaan, F., 2014).

Hasil survei data statistik pengguna internet oleh APJII (Asosiasi Penyelenggara Jasa Internet Indonesia) jumlah pengguna internet di Indonesia tahun 2016 adalah 132,7 Juta user atau sekitar $5,1 \%$ dari total jumlah penduduk indonesia sebesar 256,2 Juta. Pengguna internet terbanyak adalah di pulau Jawa dengan total penggunaan 86.339 .350 user atau sekitar $65 \%$ dari total pengguna internet. Tentu data atau fakta ini menggembirakan, terutama bagi para pengusaha atau pemilik toko online. Berdasarkan konten yang paling sering dikunjungi, pengguna internet paling sering mengunjungi online shop sebesar 82,2 Juta atau $62 \%$. Dan konten social media yang paling banyak dikunjungi adalah facebook sebesar 71,6 juta pengguna atau $54 \%$ dan urutan kedua adalah instagram sebesar 19,9 juta pengguna atau 15\% (Isparmo, 2016).

Penerapan teknologi e-commerce merupakan salah satu faktor yang penting untuk menunjang keberhasilan suatu produk dari sebuah perusahaan, untuk mempercepat dan meningkatkan penjualan cepat, dengan memanfaatkan suatu layanan secara online yang berupa e-commerce (Sunarto, A., 2009).

Pada penelitian ini, digunakan metode untuk memprediksi jumlah transaksi penjualan yang terjadi pada Distro Folder, yaitu Metode K-Nearest Neighbor. Metode K-Nearest Neighbor digunakan karena memiliki akurasi yang tinggi dengan rasio kesalahan kecil. Adapun hasil dari prediksi atau peramalan bermanfaat untuk membantu admin dalam mengambil tindakan selanjutnya (Alkhatib, K., Najadat, H., Hmeidi, I., \& Shatnawi, M. K. A., 2013).

Studi kasus penelitian ini dilakukan di Distro Folder yang merupakan perusahaan yang bergerak dalam bidang penjualan pakaian seperti baju, jaket, celana, topi, tas dan aksesoris lainnya di Sukabumi. Sistem penjualan yang berjalan selama ini adalah pembeli yang berasal dari Sukabumi bisa datang langsung ke distro, sedangkan untuk luar kota bisa melakukakan pemesanan melalui media sosial. Distro Folder belum memiliki website untuk memasarkan produk-produknya, sehingga jangkauan promosi dan jumlah transaksi masih belum maksimal. Dengan membangun website $e$ commerce yang memiliki sistem prediksi transaksi penjualan menggunakan metode K-Nearest Neighbour diharapkan dapat meningkatkan angka penjualan dengan lebih cepat, lebih luas jangkauan pasarnya serta lebih mudah dalam mengelola laporan penjualan.

\section{Metode Penelitian}

Metode pengumpulan data merupakan salah satu cara untuk menyelidiki atau menguji dengan teliti dalam mencari fakta kejelasan satu permasalahan beserta pemecahan masalah.

Beberapa teknik dalam mengumpulkan data penelitian ini adalah:

a. Observasi

Metode ini dilakukan dengan cara pengamatan langsung pada Distro Folder untuk mengamati sistem berjalan saat ini, guna mendapatkan data secara langsung pada objek yang diteliti.

b. Wawancara

Melakukan wawancara dengan pemilik distro dan pegawai yang bekerja memproses transaksi penjualan.

c. Studi Pustaka

Mencari informasi dari beberapa sumber-sumber seperti website, buku-buku, jurnal dan sebagainya. Sumber-sumber ini digunakan untuk melengkapi data-data dan informasi yang dibutuhkan dalam penelitian. 
Berikut beberapa tahapan pengembangan sistem pada penelitian ini:

a. Analisa Kebutuhan Software

Langkah ini merupakan tahap pengumpulan data, analisa interface guna menentukan solusi dari perangkat lunak yang diperlukan yang nantinya akan digunakan sebagai proses perancangan web.

b. Desain

Proses desain terbagi kedalam beberapa bagian desain yakni desain database, desain sistem dan desain interface, pada penelitian ini tools yang digunakan untuk mendesain database adalah Entity Relationship Diagram (ERD) dan Logical Relational Structure (LRS), sedangkan untuk mendukung pengembangan sistem menggunakan Unified Modeling Language (UML).

c. Code Generation

Proses pembuatan coding atau pengkodean merupakan peterjemahan desain ke dalam bahasa yang bisa dikenali oleh komputer, bahasa pemograman yang digunakan adalah bahasa pemograman php serta menggunakan javascript untuk memberikan tampilan yang tampak lebih interaktif.

d. Testing

Proses menemukan kesalahan terhadap sistem yang telah diimplementasikan kedalam sebuah software. Pada penelitian ini teknik pengujian yang akan dilakukan adalah teknik blackbox testing.

e. Support

Setelah melakukan analisis, desain dan pengkodean maka sistem yang sudah jadi akan digunakan user maka dari itu support dari pengembang masih perlu dilakukan untuk pemeriksaan secara berkala.

\section{Hasil dan Pembahasan}

\subsection{Tahapan Analisis}

Aplikasi e-commerce pada Distro

Folder ini dapat membantu mempermudah customer dalam melakukan transaksi pembelian tanpa harus datang ke Distro Folder terlebih dahulu. Customer dapat memilih dan melihat produk terbaru yang ada di Distro Folder.

Berikut spesifikasi kebutuhan (system requirement) dari website $e$ commerce pada Distro Folder:

1. Halaman Front Page:

A1. User dapat melakukan login

A2. User dapat memilih menu produk untuk melihat semua produk

A3. User dapat melakukan pembelian produk setelah login

A4. User dapat melihat keranjang belanja

A5. User dapat memilih menu info untuk melihat info terbaru

A6. User dapat memilih menu tentang kami untuk melihat alamat toko

A7. User dapat memilih menu logout untuk keluar dari halaman member

2. Halaman Administrator:

B1. Admin dapat melakukan login

B2. Admin dapat memilih menu produk untuk mengelola data produk

B3. Admin dapat memilih menu transaksi untuk mengelola dan melihat transaksi

B4. Admin dapat memilih menu pesan

B5. Admin dapat memilih menu laporan untuk melihat data pembelian sesusai hari, bulan atau tahun.

A. Use Case Diagram

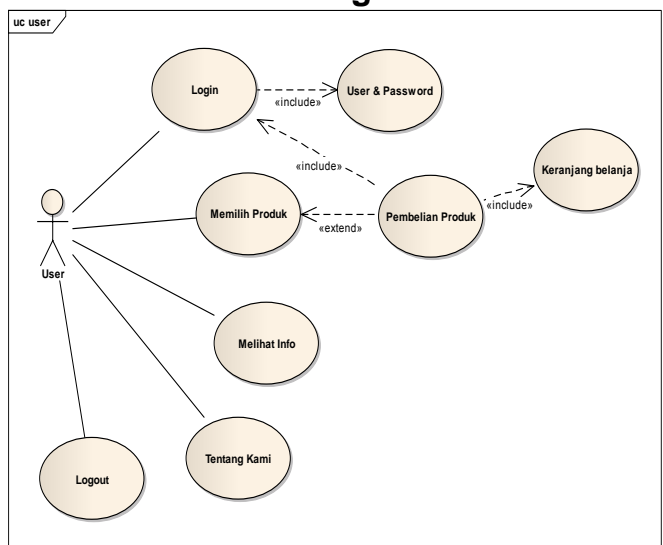

Gambar 1. Use Case Diagram Halaman User

Sumber: Hasil penelitian (2017) 


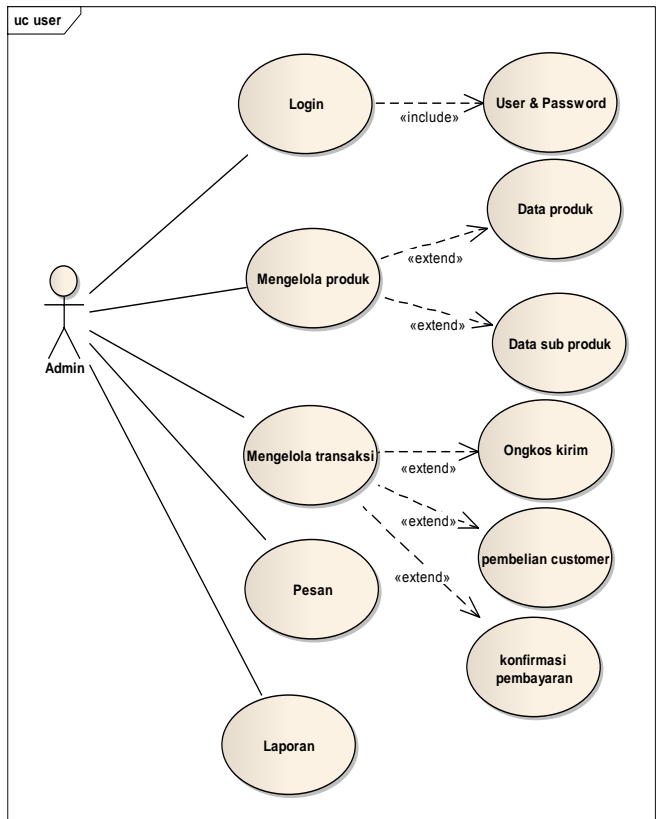

Gambar 2. Use Case Diagram Halaman Admin

Sumber: Hasil penelitian (2017)

\section{B. Activity Diagram}

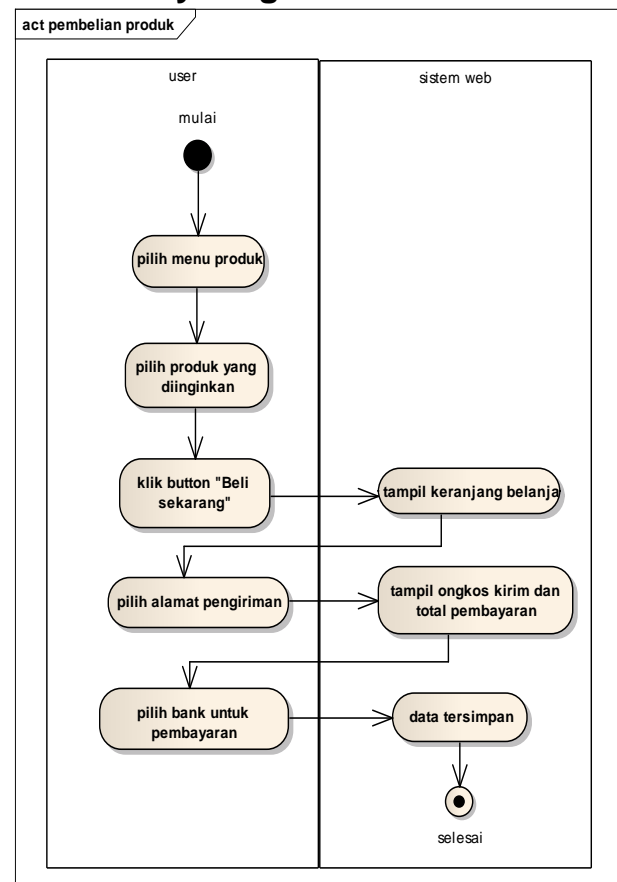

Gambar 3. Activity Diagram Pembelian Produk

Sumber: Hasil penelitian (2017)

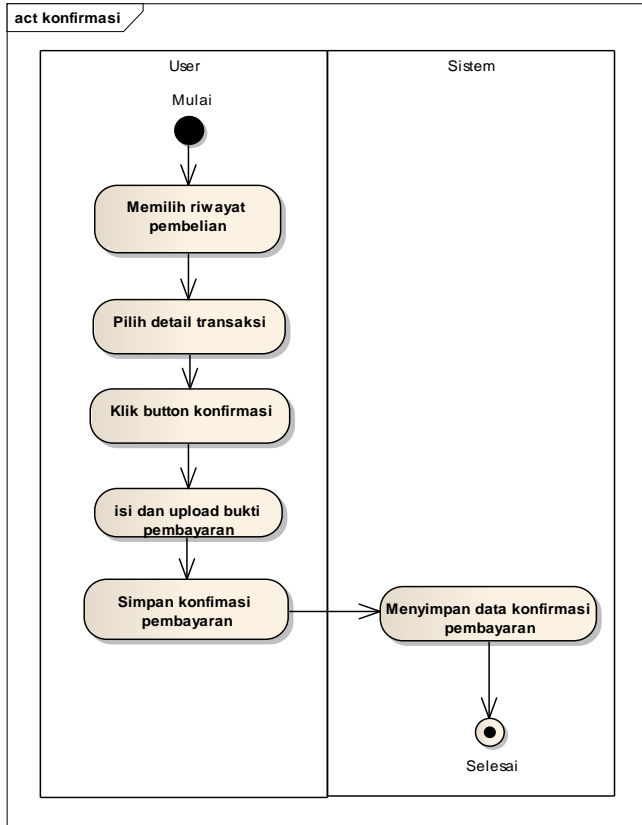

Gambar 4. Activity Diagram Konfirmasi Pembayaran

Sumber: Hasil penelitian (2017)

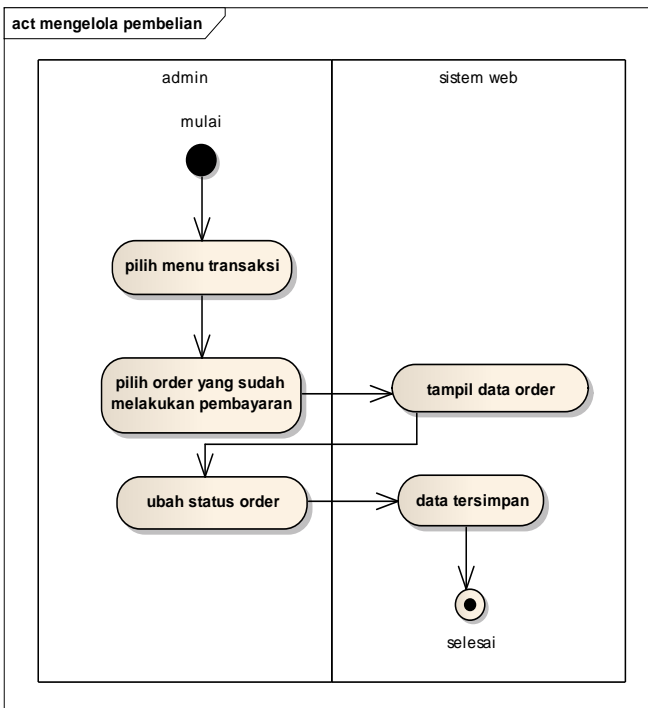

Gambar 5. Activity Diagram Mengelola Pembelian

Sumber: Hasil penelitian (2017) 
3.2. Desain

A. Database

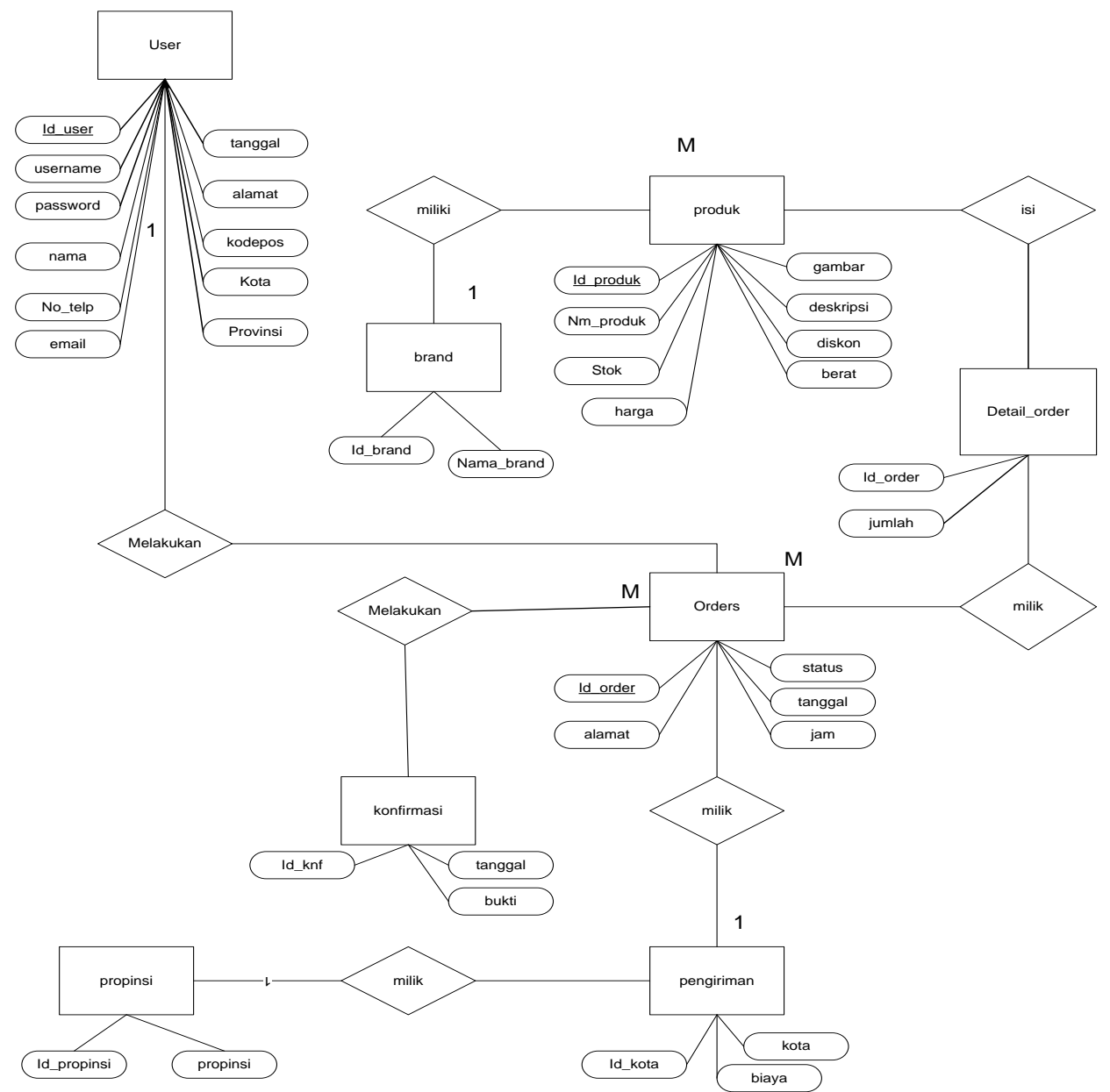

Gambar 6. Entity Relational Diagram

Sumber: Hasil penelitian (2017)

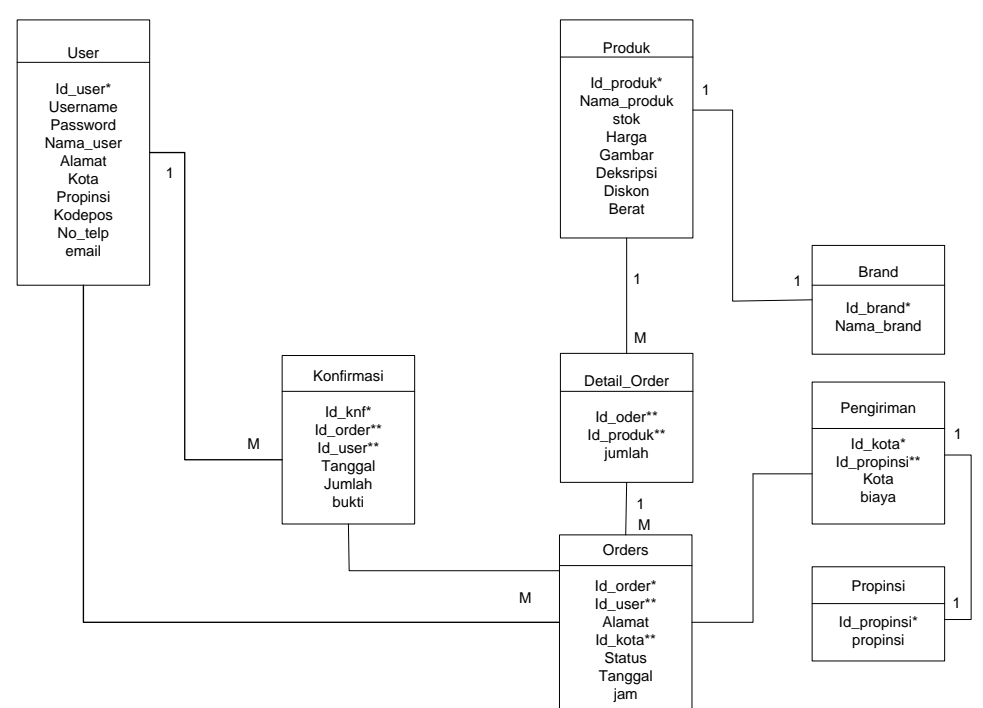

Gambar 7. Logical Record Structure

Sumber: Hasil penelitian (2017) 


\section{B. Software Architecture}

Tata letak sebuah sistem secara fisik, menampakkan bagian-bagian software yang berjalan pada bagianbagian hardware digambarkan dengan Deployment Diagram.

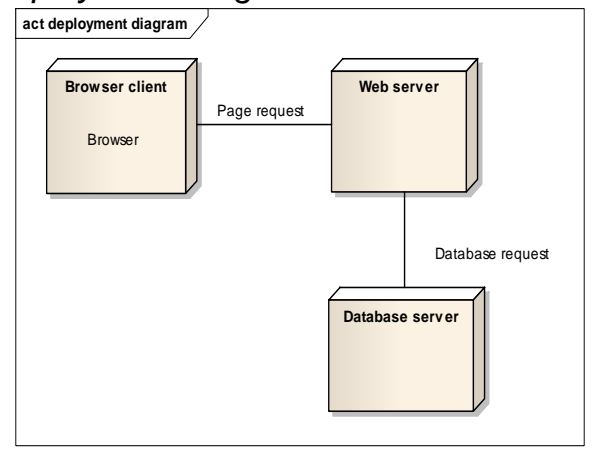

Gambar 8. Deployment Diagram

Sumber: Hasil penelitian (2017)

Struktur dan hubungan antar komponen piranti lunak termasuk ketergantungan (dependency) digambarkan dengan Component Diagram.

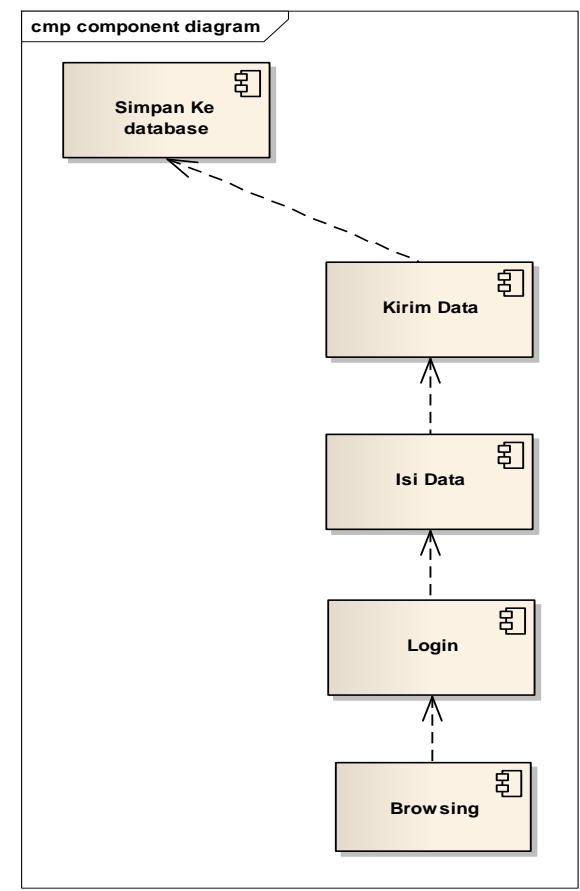

Gambar 9. Component Diagram Sumber: Hasil penelitian (2017)

\section{User Interface}
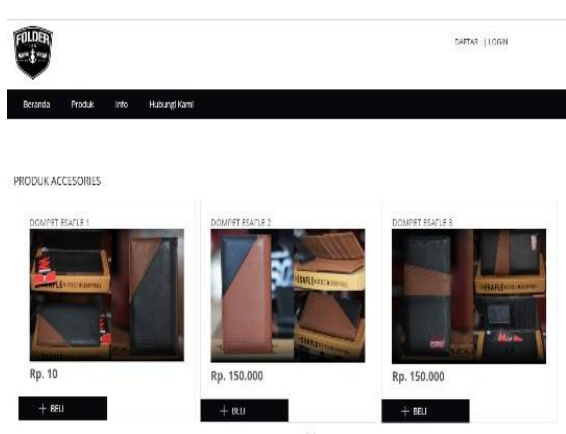

Gambar 10. Interface Menu Produk Sumber: Hasil penelitian (2017)
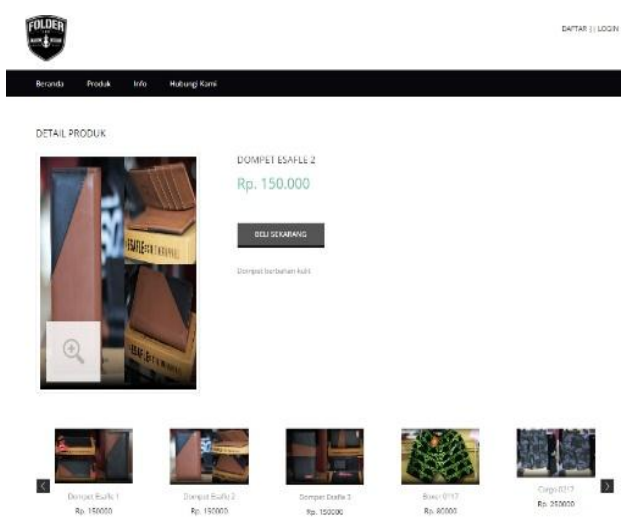

Gambar 11. Interface Menu Detail Produk

Sumber: Hasil penelitian (2017)
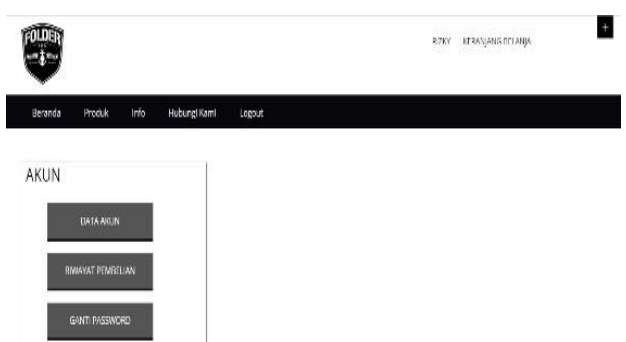

Gambar 12. Interface Menu Akun Sumber: Hasil penelitian (2017)

\section{Kesimpulan}

Berdasarkan hasil riset yang dilakukan pada Distro Folder Sukabumi serta mempelajari permasalahan yang dihadapi dan juga solusi pemecahan, maka dapat diambil kesimpulan diantaranya, dengan menggunakan website dapat memperluas jangkauan promosi atau penjualan online dan pembeli dapat lebih mudah dalam 
melakukan transaksi tanpa harus mengunjungi distro. Selain itu, dengan menerapkan metode K-Nearest Neighbor jumlah transaksi penjualan dapat diprediksi.

\section{Referensi}

Marius, P., \& Pinotaan, F. (2014). Penggunaan Internet Sektor Bisnis 2013. Asosiasi Penyelenggara Jasa Internet Indonesia. APJII.

Isparmo. (2016, November 21). Data Statistik Pengguna Internet Indonesia Tahun 2016. Retrieved from Internet Marketing \& SEO: http://isparmo.web.id/2016/11/21/dat a-statistik-pengguna-internetindonesia-2016/

Sunarto, A. (2009). Seluk beluk ecommerce. Garailmu, Jogjakarta.

Alkhatib, K., Najadat, H., Hmeidi, I., \& Shatnawi, M. K. A. (2013). Stock price prediction using k-nearest neighbor (kNN) algorithm. International Journal of Business, Humanities and Technology, 3(3), 32-44 